\title{
Environmental risk increase due to heavy metal contamination caused by a copper mining activity in Southern Brazil
}

\author{
EDISON D. BIDONE ${ }^{1 * *}$, LUCIANO LAYBAUER ${ }^{2 *}$, ZULEICA C. CASTILHOS ${ }^{1 * *}$ \\ and JOHN L. MADDOCK ${ }^{1 * *}$ \\ ${ }^{1}$ Departamento de Geoquímica, Instituto de Química, Universidade Federal Fluminense \\ 24020-007 Niterói, RJ, Brazil \\ ${ }^{2}$ Universidade Federal do Rio Grande do Sul, 91501-970 Porto Alegre, RS, Brazil \\ Manuscript received on June 19, 2000; accepted for publication on February 12, 2001; \\ presented by M. Formoso
}

\begin{abstract}
The Camaquã Copper Mines (CCM) were the main sulphide deposit in Southern Brazil and have been in operation from last century to 1996. To evaluate water contamination and environmental risk increase by heavy metals from mining operations, two points on the João Dias Creek were sampled (Station 1, background area and Station 2, contaminated area). Mining activity increased the natural weakly heavy metal fluxes by approximately $5424 \mathrm{~kg}$. $(\sim 60 \%)$ of the total metal flux, $1542 \mathrm{~kg}$. ( $\sim 49 \%)$ of dissolved and $3881 \mathrm{~kg}$ $(\sim 66 \%)$ of particulate metal flux. Total metal flux of anthropic origin was mostly due to Fe followed by $\mathrm{Cu}>\mathrm{Zn}>\mathrm{Mn}$ whereas $\mathrm{Cd}, \mathrm{As}$ and $\mathrm{Pb}$ fluxes were negligible. The potential human health hazards and risk assessment related to daily intake of water from João Dias Creek are mostly due to Mn and should be of concern for the contaminated area. The ingestion of water from station 2 represents incremental risks of $130 \%$ and $59 \%$ respectively, considering the non-carcinogenic and the carcinogenic effects. The real increase of human health hazards may be greater than those related to the total concentrations since Mn and As dissolved concentrations were 5.5 and 2.0 higher than acceptable, respectively.
\end{abstract}

Key words: water contamination, environmental risk, heavy metals, copper mining.

\section{INTRODUCTION}

Recent research carried out in some rivers of the Rio Grande do Sul, the southermost brazilian state, showed significant loads of heavy metals transported by their waters (Baisch 1994, Travassos and Bidone 1995, Hatje et al. 1998). Large amounts of heavy metals were found to be related to mining activities (Baisch 1994, Laybauer 1995, 1998, Laybauer and Bidone 1998a, 1998b) in areas whose geol-

Correspondence to: Luciano Laybauer

E-mail: luciano.laybauer@ig.com.br

*Curso de Pós-graduação em Geociências

**E-mail: geobida@vm.uff.br ogy includes sulphide mineralisation, like the $\mathrm{Ca}$ maquã Copper Mines (CCM), the area upon which this study is focused. Because sulphides are easily oxydised and dissolved in surface and groundwater environments and the exposure of these minerals to atmospheric oxygen results in one of the most acid producing of all known weathering reactions (Förstner and Wittmann 1981, Drever 1982), there is a feedback or autocatalytic effect whereby the acidification process contributes to further ore dissolution and increases the metal concentration in fluvial waters. Given the potential risk to human and ecosystem health associated with heavy metal 
toxicity, special attention must be payed to sulphide mining facilities and the manifestations of their operation in water courses which drain them. These latter are the principal vectors which transfer potential contaminants to adjacent areas as well as to the trophic chain.

In order to evaluate potential risk associated with heavy metal contamination arising from mining activities, of fluvial waters in the CCM area, three aspects are emphasised in this study. Firstly, given that the rock types in the CCM drainage basin and the soils originated from them, release significant amount of heavy metals into the river, the anthropogenic (from CCM mining facilities) and natural inputs of heavy metals are mixed all along the fluvial waters. Therefore, given that the anthropogenic component of the metal concentrations could be masked by natural sources, special attention should be given to the separation of natural and anthropogenic heavy metal contents. Secondly, possible changes, due to mining activities, in the availability of metals in solid phases, sediment and suspended solids, should be identified and quantified. Even though quality criteria in the legislation refer to total metal concentrations in water, the dissolved fraction is certainly more easily available to biota than that associated with suspended particles and it is thus advisable to analyse the two fractions separately. Thirdly, the increment in risk potential which can be imputed to mining activities, compared to the risk potential which occurs naturally, should be quantified, by comparison between the rivers influenced by mining activities and others in a non-impacted control area within the general study area.

The CCM area is very favourable for a case study using the proposed approach because the only anthropic activity which exists in the area is mining.

\section{STUDY AREA}

The study area lies between longitudes $52^{\circ} 20^{\prime}$ and $52^{\circ} 30^{\prime} \mathrm{W}$ and latitudes $30^{\circ} 50^{\prime}$ and $31^{\circ} 00^{\prime} \mathrm{S}$, and it is situated about $300 \mathrm{~km}$ west of Porto Alegre, capital of the State of Rio Grande do Sul, Southern Brazil.
This region has a mesothermic temperate climate with $1450 \mathrm{~mm}$ mean annual precipitation and a mean temperature around $18^{\circ} \mathrm{C}$ (Laybauer 1995).

The CCM are presently being closed down but were the main copper mines of southern Brazil and have operated since the last century. The watershed where the mining operations took place has an area of approximately $310 \mathrm{~km}^{2}$. The main drainage of this basin is the João Dias Creek, which flows into the upper course of the Camaquã river. The Camaquã river is an important tributary to the Patos Lagoon, a very important Brazilian coastal lagoon system.

The CCM mined a sedimentary sequence of Neoproterozoic age, formed mainly by conglomerates, sandstones and siltites, with only minor andesites. The copper ore occurs as sulphide veins and disseminated mineralization, mostly in conglomerates and sandstones of Neoproterozoic-Cambrian age (Laybauer 1995, Laybauer and Bidone 1998a). Mining was carried out using both underground and open pit operations. During the nineteen eighties, until the beginning of the nineties, when the present study was undertaken, the main mining operation was developed as an open pit. The principal environmental control device used was a tailings dam that received mine rejects and effluents with a large amount of suspended solids, including fine grains, from the ore dressing (crushing, milling and flotation), partially associated with waters arising from others mining operations (water pumping from underground and open pit mine) and with the leaching of stock and tailing piles. However, despite the existence of this tailings dam, a large part of these rejects and effluents were dumped directly into João Dias Creek (Laybauer 1995, Laybauer and Bidone 1998a, 1998b).

\section{MATERIALS AND METHODS}

As a general rule, it is advisable to start the environmental risk assessment with the "worst case" study. Extreme exposure patterns should be considered, with reference to the population sub-group at 
the highest exposure risk; conservative hypotheses may be assumed, and temporal peaks of pollution may also be used for assessment (Zapponi 1988). Virtually all environmental laws may be said to rest upon a single, generally unstated concept: negative default. By this it is meant that for any given environmental risk, we must assume the worst situation for the estimation of possible effects, so that we can assume that no effects worse than these can occur (Wilson 1991).

Water sampling was carried out during one week in december 93, a month characterized by low river water level in the region, and consequentely a period of low water dilution capacity. Two points on the João Dias Creek were sampled in this study. Station 1 represents the upstream control area or the natural background, and station 2 is situated downstream from the region of mining activities, close to the mouth of João Dias Creek basin.

Water samples were collected in 1 litre polyethylene bottles and $250 \mathrm{~mL}$ of these samples were filtered through $0,45 \mu \mathrm{m}$ membranes to separate the dissolved elements, this procedure being the standard operationally defined classification, rather than a scientifically based absolute separation (Hall et al. 1996). Both non-filtered and filtered water samples were preserved with $\mathrm{HNO}_{3}$ 1:1 and kept at $4^{\circ} \mathrm{C}$ in polyethylene bottles until analysis. Sampling bottles, the filtration equipment and other glass and polyethylene wares were leached in a nitric acid bath and rinsed thoroughly with double-distilled deionised water prior to use (APHA 1985). Analyses of metals were carried out by FAAS ( $\mathrm{Cu}, \mathrm{Zn}, \mathrm{Mn}$ and $\mathrm{Fe}$ ), GFAAS ( $\mathrm{Pb}, \mathrm{Cd}$ and $\mathrm{Al})$ and HGAAS (As) using a Perkin Elmer Model 2380 Atomic Absorption Spectrophotometer with HGA 400 Graphite Furnace, AS 40 Autosampler and MHS-10 hydride generation system (Laybauer 1995). Procedural blanks were measured in all determinations.

The concentrations of heavy metals bound to particulate material were obtained by subtracting the element concentrations measured in filtered samples from the total concentrations in non-filtered water samples.

In order to separate natural heavy metals originating from weathering of rocks and soils from those related to mining activities, we have employed the methodological approach originally proposed by Bidone in 1992 and subsequently tested in various case studies (Travassos and Bidone 1995, Laybauer 1995, Hatje et al. 1998, Laybauer and Bidone 1998a).

The estimated health hazard associated with human exposure to heavy metals in a miningimpacted site can be compared with that from a background site by employing potential human health hazard assessment at a screening level (USEPA 1989). Although this assessment may be simplistic, it permits easy comparison between populations under different levels of exposure to a given pollutant or to different pollutants. Overall, this method allows the evaluation of differences between contaminated and background areas, so that the toxicological - rather than simply statistical - significance of the contamination can be ascertained. A screening approach aims to identify potentially important factors rapidly, pollutants or phenomena of the contaminated situation, to enable the elimination of those of lesser significance (IAEA 1990).

Two different approaches are used in the USEPA health risk assessment process, in order to characterize potential noncarcinogenic effects and potential carcinogenic effects (USEPA 1989). For noncarcinogenic substances, a Hazard Quotient (HQ) approach is used, which assumes that there is a level of exposure (i.e., RfD = Reference Dose) below which it is unlikely that even sensitive populations will experience adverse health effects. HQ is defined as the ratio of a single substance exposure level (E) to a reference of dose $\left(\mathrm{HQ}=\mathrm{E} \cdot \mathrm{RfD}^{-1}\right)$. When HQ exceeds unity, there may be concern for potential health effects caused by human non-carninogenic substances. The Hazard Index (HI) is equal to the sum of more than one hazard quotient for multiple substances and/or multiple exposure pathways. As with the HQ, when the HI exceeds the unity, there 
may be concern for potencial health effects. It is belived that for carcinogenic substances there is essentially no level of exposure that does not pose a finite probability, however small, of generating a carcinogenic response. It assumes that a small number of molecular events can evoke changes in a single cell that can lead to uncontrolled cellular proliferation and eventually to a clinical state of disease. That is, no dose is thought to be risk-free. For these substances, there is a two part evaluation in which the substance is first assigned a weight-of-evidence classification and then a slope factor is calculated. The weight-of-evidence classification is representative of the likehood that the agent is a human carcinogen and it ranged from classes A to E. The slope factors are calculated only for highest potential carcinogens, which are designated to class "A", known human carcinogens and "B1" and "B2", probable human carcinogens. The slope factor (SF) is a toxicity value that defines quantitatively the relationship between dose and response. To characterize potential carcinogenic effects, probabilities that an individual will develop cancer over a lifetime of exposure are estimated from projected intakes and slope factor. Potential noncarcinogenic effects of carcinogenic substances were evaluated in this study where appropriate RfDs are available.

In this study, a single exposure pathway was considered, the ingestion of contaminated water. The estimated exposure level (E) was obtained by multiplication of mean heavy metals concentrations in the unfiltered samples (as determined by Brazilian environmental legislation, which follows USEPA norms) by the adult human ingestion rate $\left(2 \mathrm{~L} . \mathrm{d}^{-1}\right)$ and divided by $70 \mathrm{~kg}$, considered as the human adult average weight.

\section{RESULTS AND DISCUSSION}

Table I shows the basic experimentally obtained data used in this study.

Various distinct modifications in metal behaviour can be observed in Table I, between the control area (Station 1) and the mining impacted area
(Station 2): (i) $\mathrm{Cu}, \mathrm{Zn}$ and $\mathrm{Fe}$ total, dissolved and particulate concentrations all increased (T, D and P) but the percentage of these metals in dissolved form (\%D) decreased. (ii) Concentrations of As and $\mathrm{Mn}$ in all forms similarly increased but the fraction in dissolved form also increased. (iii) $\mathrm{Cd}$ was the unique element that showed reduction in total, dissolved and particulate concentrations. (iv) Compared with the other metals, $\mathrm{Pb}$ and $\mathrm{Al}$ total concentrations showed no appreciable change and, for this reason, aluminium was chosen as an indicator for material of natural origin.

Data for contaminant concentrations and physical forms in water are given in Table I but the influence of mining operations and these effects on the partitioning among phases can be shown more clearly by evaluating the fluxes, using the procedure defined below, which allows the separation of natural and anthropic components.

This approach is based on the mass balance of heavy metal fluxes between river segments, considering both the natural and anthropogenic components, using a natural tracer (Travassos and Bidone 1995, Laybauer 1995, Hatje et al. 1998, Laybauer and Bidone 1998a). This approach is synthesized in the following equation:

$$
\begin{gathered}
\mathrm{AC}=(\mathrm{MeO}-\mathrm{MeI}) \\
-\left[(\mathrm{EiO}-\mathrm{EiI}) \times\left(\mathrm{MeOB} \cdot \mathrm{EiOB}^{-1}\right)\right]
\end{gathered}
$$

where:

$\mathrm{AC}=$ the anthropogenic component of the total metal flux increase in the river segment,

$\mathrm{MeO}=$ the outflux of the metal from the river segment considered,

$\mathrm{MeI}=$ the influx of the metal into the river segment considered,

$\mathrm{MeO}-\mathrm{MeI}=$ the total metal flux increase (i.e., total metal balance) in the river segment,

$\mathrm{EiO}=$ the natural tracer outflux from the river segment considered, 
TABLE I

Discharges and heavy metal concentrations in the João Dias Creek.

\begin{tabular}{|c|c|c|c|c|c|c|c|c|c|c|}
\hline $\begin{array}{c}\text { Sampling } \\
\text { Station }\end{array}$ & $\begin{array}{c}\mathrm{Q} \\
\left(\mathrm{m}^{3} / \mathrm{s}\right)\end{array}$ & $\begin{array}{l}\text { Concentrations } \\
\left(\mu \mathrm{g} . \mathrm{L}^{-1}\right)\end{array}$ & $\mathrm{Cu}$ & $\mathrm{Zn}$ & $\mathrm{Cd}$ & As & $\mathrm{Pb}$ & $\mathrm{Mn}$ & $\mathrm{Fe}$ & $\mathrm{Al}$ \\
\hline \multirow{4}{*}{1} & \multirow{4}{*}{0.2} & Total $(\mathrm{T})^{1}$ & 60 & 16 & 0.60 & 1.38 & 6.8 & 60 & 1150 & 19 \\
\hline & & Dissolved (D) ${ }^{2}$ & 47 & 12 & 0.25 & 0.65 & 3.8 & 20 & 370 & 2 \\
\hline & & Particulate $(\mathrm{P})^{3}$ & 13 & 4 & 0.35 & 0.73 & 3.0 & 40 & 780 & 17 \\
\hline & & $\%$ Dissolved $(\% \mathrm{D})^{4}$ & 78 & 75 & 42 & 47 & 56 & 33 & 32 & 11 \\
\hline \multirow{4}{*}{2} & \multirow{4}{*}{6.0} & Total $(\mathrm{T})^{1}$ & 179 & 128 & 0.31 & 2.20 & 7.7 & 160 & 2040 & 15 \\
\hline & & Dissolved (D) ${ }^{2}$ & 87 & 80 & 0.23 & 1.32 & 5.9 & 110 & 595 & 2 \\
\hline & & Particulate $(\mathrm{P})^{3}$ & 92 & 48 & 0.08 & 0.88 & 1.8 & 50 & 1445 & 13 \\
\hline & & $\%$ Dissolved $(\% \mathrm{D})^{4}$ & 48 & 63 & 74 & 60 & 77 & 69 & 29 & 13 \\
\hline
\end{tabular}

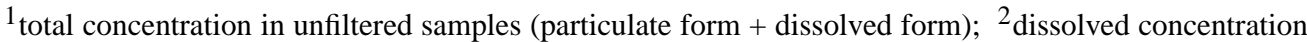
(fraction $<0,45 \mu \mathrm{m}$ ); ${ }^{3}$ concentration bound to suspended particulate material (fraction $>0,45 \mu \mathrm{m}$ ); ${ }^{4}$ percentage of the total concentration in the dissolved form.

EiI $=$ the natural tracer influx into the river segment considered,

$\mathrm{EiO}-\mathrm{EiI}=$ the total tracer flux increase (i.e., total tracer balance) in the river segment,

$\mathrm{MeOB}=$ the metal outflow from the natural background river segment,

$\mathrm{EiOB}=$ the natural tracer outflux from the natural background river segment.

The member of the equation $[(\mathrm{EiO}-\mathrm{EiI}) \times$ $\left.\left(\mathrm{MeOB} . \mathrm{EiOB}^{-1}\right)\right]$ corresponds to the natural component of the total metal flux increase in the river segment considered.

The mass balance calculations were performed considering steady state conditions.

The terms "metal influx" and "metal outflux" (in kg.week ${ }^{-1}$ in this study) were estimated by multiplying metal concentrations for three different forms (i.e., total metal or unfiltered water $=$ particulate + dissolved; dissolved fraction and the fraction bounded to suspended particulate material), by the river water flow $(\mathrm{Q})$ at the corresponding sampling stations.

This research used $\mathrm{Al}$ as the natural tracer, because this element is always present in the same abundance in the fluvial waters throughout the basin, with small standard deviation, and because the concentrations of this element are homogeneously distributed in all samples from the rocks, soils and uncontaminated sediments from João Dias Creek basin. Laybauer (1995) and Laybauer and Bidone (1998a) have used $\mathrm{Pb}$ for the same purpose in other evaluations carried out in this area.

The mass balances of metal fluxes in the João Dias Creek are presented in Table II.

There are large anthropic components in the metal flux increases, both in particulate and dissolved forms, which occur between the control station 1 and station 2: $5424 \mathrm{~kg}$. week $^{-1}$, or about $60 \%$ of total metal flux (T), $1542 \mathrm{~kg}$. week ${ }^{-1}$ or about $49 \%$ of dissolved metal flux and $3881 \mathrm{~kg}$.week ${ }^{-1}$ or about $66 \%$ of particulate metal flux.

The percentage of the total anthropic metal flux (\% Me Anthrop., Table II) related to the metals considered in this study shows: Fe has the greatest increase, followed by $\mathrm{Cu}>\mathrm{Zn}>\mathrm{Mn}$. Anthropic increases of $\mathrm{Cd}, \mathrm{As}$ and $\mathrm{Pb}$ are generally lower than the natural flux increases of these metals, being practically negligible ( $<1 \%$, of total fluxes). 
TABLE II

Mass balance of metal fluxes $\left({\left.\mathrm{kg} . w e e k^{-1}\right)}\right.$ in the João Dias Creek in CCM drainage basin.

\begin{tabular}{|c|c|c|c|c|c|c|c|c|c|c|}
\hline Fluxes & & $\mathrm{Cu}$ & $\mathrm{Zn}$ & $\mathrm{Cd}$ & As & $\mathrm{Pb}$ & $\mathrm{Mn}$ & $\mathrm{Fe}$ & $\mathrm{Al}$ & Total \\
\hline \multirow{5}{*}{$\mathrm{T}^{1}$} & 1 (Input) & 7 & 2 & 0.1 & 0.2 & 1 & 7 & 139 & 2 & \\
\hline & 2 (Output) & 650 & 463 & 1.1 & 8.0 & 28 & 581 & 7,400 & 54 & \\
\hline & Increase $^{4}$ & 643 & 461 & 1.0 & 7.8 & 27 & 573 & 7,260 & 52 & 9,030 \\
\hline & Natural $^{5}$ & 165 & 44 & 1.6 & 3.8 & 18 & 165 & 3,160 & 52 & 3,600 \\
\hline & Anthropogenic ${ }^{6}$ & 478 & 417 & -0.6 & 4.0 & 9 & 408 & 4,110 & 0 & 5,420 \\
\hline \multirow{5}{*}{$\mathrm{D}^{2}$} & 1 (Input) & 6 & 1 & 0.0 & 0.1 & 0 & 2 & 45 & 0 & \\
\hline & 2 (Output) & 314 & 290 & 0.8 & 4.8 & 21 & 399 & 2,160 & 7 & \\
\hline & Increase $^{4}$ & 308 & 289 & 0.8 & 4.7 & 21 & 397 & 2,110 & 7 & 3,140 \\
\hline & Natural $^{5}$ & 165 & 42 & 0.9 & 2.3 & 13 & 70 & 1,300 & 7 & 1,600 \\
\hline & Anthropogenic ${ }^{6}$ & 143 & 247 & -0.1 & 2.4 & 8 & 327 & 815 & 0 & 1,540 \\
\hline \multirow{5}{*}{$\mathrm{P}^{3}$} & 1 (Input) & 2 & 1 & 0.0 & 0.1 & 0 & 5 & 94 & 2 & \\
\hline & 2 (Output) & 336 & 173 & 0.3 & 3.2 & 6 & 181 & 5,240 & 47 & \\
\hline & Increase $^{4}$ & 334 & 172 & 0.3 & 3.1 & 6 & 176 & 5,150 & 45 & 5,890 \\
\hline & Natural $^{5}$ & 0 & 2 & 0.8 & 1.5 & 5 & 94 & 1,860 & 45 & 2,010 \\
\hline & Anthropogenic ${ }^{6}$ & 334 & 170 & -0.5 & 1.6 & 1 & 82 & 3,290 & 0 & 3,880 \\
\hline $\mathrm{T}^{1}$ & $\%$ Metals related & 9 & 8 & 0 & $<1$ & $<1$ & 7 & 76 & 0 & \\
\hline $\mathrm{D}^{2}$ & to anthropogenic & 10 & 16 & 0 & $<1$ & $<1$ & 21 & 53 & 0 & \\
\hline $\mathrm{P}^{3}$ & sources & 9 & 4 & 0 & $<1$ & $<1$ & 2 & 85 & 0 & \\
\hline
\end{tabular}

${ }^{1} \mathrm{~T}=$ total flux, considers the discharge at the sampling station and, the total concentration in unfiltered samples (particulate form + dissolved form); ${ }^{2} \mathrm{D}=$ dissolved flux, considers the discharge at the sampling station and, the concentration in the fraction $<0,45 \mu \mathrm{m} ;{ }^{3} \mathrm{P}=$ particulate flux, considers the discharge at the sampling station and, the concentration bound to suspended particulate material (fraction $>0,45 \mu \mathrm{m}$ ); ${ }^{4}$ Difference between the output flux and the input flux in kg.week ${ }^{-1} ;{ }^{5}$ Natural component of the flux increase; ${ }^{6}$ Antropogenic component of the flux increase.

The anthropogenic component increase in the total flux of metals in the João Dias Creek, nearly 5.4 ton.week $^{-1}$, is large in both environmental and economic terms. For example, for copper alone, the operational losses accounted for as total anthropogenic increase in creek load are $478 \mathrm{~kg} . \mathrm{week}^{-1}$, nearly a ton of copper every two weeks, without considering material retained in the tailing dam.

It is worth considering whether the fluxes in Table II are under- or overestimated by the normalization method employed for their calculation. Aluminium is used as a measure of natural sources of the metals. Given the constancy of the model of natural sources, e.g. the leaching of soils, aluminium concentrations (T, D and P) should ideally be the same at all sampling stations along the river. Table I shows that this is only the case for the dissolved concentration, "D", $\left(2 \mu \mathrm{g} . \mathrm{L}^{-1}\right)$. Thus the dissolved aluminium flux increases by a factor of 30 , from 0.24 to $7.2 \mathrm{~kg} . \mathrm{w}^{-1}$, between stations 1 and 2 , exactly the same as the change in water discharge between the two stations. Total $\mathrm{Al}$ concentrations differ, from $19 \mu \mathrm{g} . \mathrm{L}^{-1}$ at Station 1, to $15 \mu \mathrm{g} . \mathrm{L}^{-1}$ at Station 2, resulting in a factor of 24 in the respective fluxes, 2.3 
kg.week ${ }^{-1}$ and 54.4 kg.week ${ }^{-1}$, rather than the ideal factor (30-fold). This result may underestimate the natural flux of metals and consequently overestimate the anthropic contributions to the increases in fluxes between the two stations. Obviously, the smaller the natural component (which is estimated from the aluminium flux) of the increase between the stations, in the flux of a metal, the smaller will be the oversestimate in the anthropic component. A sensitivity test can be made by designating a value of $19 \mu \mathrm{g} . \mathrm{L}^{-1}$ for total aluminium concentrations at both stations. On this basis, the anthropic fluxes of (total) metals in Table II would be overestimated by $1 \%(\mathrm{Zn}) ; 10 \%$ $(\mathrm{Cu}) ; 11 \%(\mathrm{Mn}) ; 22 \%(\mathrm{Fe}) ; 26 \%(\mathrm{As}) ; 61 \%(\mathrm{~Pb})$ and $92 \%(\mathrm{Cd})$.

In addition to the above observations, the data in Table II can be seen from the point of view of environmental management of heavy metal contamination in the area, in terms of (the more usually employed) metal concentrations.

Given that the concentrations and fluxes of metals at station 1 are of natural origin and the evaluation method proposed here essentially assumes steady state, i.e. the increase factor in flow rate between stations 1 and 2 is constant, the fluxes are necessarily directly (linearly) proportional to concentrations, so that the inverse of this is also true and the concentrations must also have two separately determinable components, natural and anthropic. These can be used to evaluate the incremental risk to the environment atributable to heavy metals originating from mining operations.

This approach can be expressed as follows: let $\mathrm{AC}=$ anthropogenic component of the metal flux increase / metal flux increase, then: ACC $=$ anthropogenic component of the metal concentration at station $2=\mathrm{AC} \times$ metal concentration at station 2 . These data are presented in Table III.

These ACC data (anthropogenic component of the metal concentration) at station 2 are used to evaluate the increment in environmental risk due to the mining operation.

$\mathrm{Al}, \mathrm{Fe}, \mathrm{Pb}$ and $\mathrm{Cu}$ are classified as noncarcino- genic substances but sufficient data is not available to derive their reference doses, so that for these contaminants it is not possible to estimate the hazard quotient for human health. However, their most important human toxicological effects can be remarked. The ambient water quality criterion for $\mathrm{Pb}$ is recommended to be the same as the existing drinking water standard, which is $50 \mu \mathrm{g} . \mathrm{L}^{-1}$. For $\mathrm{Cu}$, there are the organoleptic data for controlling undesirable taste and odor quality of ambient water, the estimated limit level being $1 \mathrm{mg} . \mathrm{L}^{-1}$. Of course, organoleptic data have no demonstrated relationship to potential adverse human health effects. Table I shows that the total concentrations of $\mathrm{Cu}$ and $\mathrm{Pb}$ levels in water from both areas are around 10 times smaller than the above limits. No adverse effects of environmental exposure to $\mathrm{Fe}$ and $\mathrm{Al}$ have been conclusively demonstrated. As and Cd not only have reference doses but also slope factors have been defined. Arsenic is a recognized human carcinogen, Class " $\mathrm{A}$ " while $\mathrm{Cd}$ is a probable human carcinogen, Class "B1". However, it is also important to evaluate the noncarcinogenic effects of contamination by these elements. For Mn, only noncarcinogenic effects can be evaluated, because it is classified as a Class D carcinogen, for which no slope factor is defined. $\mathrm{Zn}$ is considered noncarcinogenic and a RfD value is available.

Table IV presents potential human health hazards and risk assessment by heavy metals exposure by ingestion of water from the background and contaminated sites. Table IV shows the slope factor values (mg. Kg $\left.{ }^{-1} \cdot \mathrm{d}^{-1}\right)^{-1}$ and weight-of-evidence classification (class), for the carcinogenic substances and the reference dose (RfD) in $\mathrm{mg} \cdot \mathrm{Kg}^{-1} \cdot \mathrm{d}^{-1}$ for noncarcinogenic effects, as well as, hazard quotient (HQ), hazard index (HI). The exposure levels (E in mg.kg ${ }^{-1} \cdot \mathrm{d}^{-1}$ ) were calculated by multiplication of mean heavy metal concentrations in the unfiltered sample by the adult human ingestion rate $\left(2 \mathrm{~L} . \mathrm{d}^{-1}\right)$ and divided by $70 \mathrm{~kg}$, considering the weight average human adult.

The results show that $\mathrm{HI}$ for noncarcinogenic 


\section{TABLE III}

Estimates of the anthropogenic component of metal concentrations in the João Dias Creek, downstream from the CCM mining facilities (based on station 2 data).

\begin{tabular}{c|c|c|c|c|c|c|c|c}
\hline & & $\mathrm{Cu}$ & $\mathrm{Zn}$ & $\mathrm{Cd}$ & $\mathrm{As}$ & $\mathrm{Pb}$ & $\mathrm{Mn}$ & $\mathrm{Fe}$ \\
\hline & $\mathrm{T}$ & 0.74 & 0.90 & -0.59 & 0.51 & 0.32 & 0.71 & 0.57 \\
$\mathrm{AC}^{1}$ & $\mathrm{D}$ & 0.46 & 0.85 & -0.12 & 0.52 & 0.37 & 0.82 & 0.39 \\
& $\mathrm{P}$ & 1.00 & 0.99 & -2.10 & 0.51 & 0.14 & 0.47 & 0.64 \\
\hline \multirow{3}{*}{$\mathrm{ACC}^{2}$} & $\mathrm{~T}$ & $132 / 179$ & $115 / 128$ & - & $1.13 / 2.20$ & $2.4 / 7.7$ & $114 / 160$ & $1154 / 2040$ \\
& $\mathrm{D}$ & $40 / 87$ & $68 / 80$ & - & $0.68 / 1.32$ & $2.2 / 5.9$ & $91 / 110$ & $230 / 595$ \\
& $\mathrm{P}$ & $92 / 92$ & $47 / 48$ & - & $0.45 / 0.88$ & $0.3 / 1.8$ & $23 / 50$ & $924 / 1445$ \\
\hline
\end{tabular}

${ }^{1} \mathrm{AC}=$ anthropogenic component of the metal flux increase divided by metal flux increase at station 2;

${ }^{2} \mathrm{ACC}=$ anthropogenic component of the metal concentration at station $2=\mathrm{AC} \times$ metal concentration at station 2. The two values presented are ACC and measured concentration $\left(\mu \mathrm{g} . \mathrm{L}^{-1}\right)$.

TABLE IV

Potential human health hazard and risk assessment by heavy metals exposure by water ingestion from background and contaminated stations in the João Dias Creek.

\begin{tabular}{|c|c|c|c|c|c|c|}
\hline \multirow[t]{2}{*}{$\begin{array}{l}\text { Heavy } \\
\text { metal }\end{array}$} & \multirow{2}{*}{$\begin{array}{c}\text { Slope factor } \\
\left(\mathrm{mg} \cdot \mathrm{kg}^{-1} \cdot \mathrm{d}^{-1}\right)^{-1} \\
(\text { Class })\end{array}$} & \multirow[t]{2}{*}{$\begin{array}{c}\text { RfD } \\
\left(\mathrm{mg} \cdot \mathrm{kg}^{-1} \cdot \mathrm{d}^{-1}\right)\end{array}$} & \multicolumn{2}{|c|}{$\begin{array}{c}\text { Background area } \\
\text { Station } 1\end{array}$} & \multicolumn{2}{|c|}{$\begin{array}{c}\text { Contaminated area } \\
\text { Station } 2\end{array}$} \\
\hline & & & $\mathrm{HQ}^{1}$ & Risk & $\mathrm{HQ}^{1}$ & Risk \\
\hline As & $1.5(\mathrm{~A})$ & 3 E-04 & 0.13 & 5.9 E-05 & 0.21 & 9.4 E-05 \\
\hline $\mathrm{Cd}$ & 1.8 E-03 (B1) & 5 E-04 & 0.03 & 3.1 E-08 & 0.02 & $1.6 \mathrm{E}-08$ \\
\hline $\mathrm{Mn}$ & (D) & $5 \mathrm{E}-03$ & 0.34 & & 0.91 & \\
\hline $\mathrm{Zn}$ & & 3 E-01 & $<0.01$ & & 0.01 & \\
\hline $\mathrm{HI}^{2}$ & & & 0.50 & & 1.15 & \\
\hline Risk & & & & 5.9 E-05 & & 9.4 E-05 \\
\hline
\end{tabular}

${ }^{1} \mathrm{HQ}=$ hazard quotient (the ratio of a single substance exposure level over a specified time period to a reference dose for that substance derived from a similar exposure period); ${ }^{2} \mathrm{HI}=$ hazard index (the sum of more than one hazard quotient for multiple substances and/or multiple pathways).

effects, estimated for the background area (Station 1) is smaller than the unity, meaning no probable public health threat. However, for the contaminated area (Station 2), the HI estimated is higher than the unity. Thus, there may be concern for potencial human health effects. Manganese seems to be the prin- cipal component responsible for this, since its HQ is 0.91 .

The ingestion of water from station 2 (contaminated by mining), compared to the water of station 1 , represents incremental risks of $130 \%$ and $59 \%$ respectively, considering the noncarcinogenic and the 
carcinogenic effects.

For the maximum protection of the human health from the potencial carcinogenic effects due to exposure of chemicals (e.g., $\mathrm{Cd}$ and $\mathrm{As}$ ) in drinking water, the ambient water concentration should be zero, based on the non-threshold assumption for these chemicals. However, based on considerations of cost and technical feasability, lifetime risks of $10^{-6}$ to $10^{-4}$ are considered acceptable for carcinogens in drinking water (Federal Register 1980, Kocher and Hoffmann 1991).

Concluding, health risks increase due to contamination by noncarcinogenic (mainly $\mathrm{Mn}$ ) and carcinogenic (mainly As) substances are caused by the increases in concentrations, by factors of around 3 and 1.5 respectively (Table IV and Table I). The real increase may be greater because the dissolved concentrations of Mn and As increased more, by factors around 5.5 and 2, respectively. This may mean that the amounts which are probably of anthropic origin and are probably bio-available, increased by $80 \%$, for Mn, and $50 \%$, for As (Table III).

\section{CONCLUSIONS}

Mining activity in CCM increase the total concentrations of $\mathrm{Cu}, \mathrm{Zn}, \mathrm{As}, \mathrm{Mn}$ and $\mathrm{Fe}$ in the water of João Dias Creek. $\mathrm{Al}$ and $\mathrm{Pb}$ practically showed no important changes and $\mathrm{Cd}$ concentration decreased from station 1 (unpolluted site) to station 2, under mining influence. Besides these increases, mining operations and their releases, produces changes in metal partitioning. The main differences observed from station 1 to station 2, were the following: (i) $\mathrm{Cu}, \mathrm{Zn}$ and $\mathrm{Fe}$ total, dissolved and particulate concentrations all increased but the percentage of these metals in dissolved form decreased; (ii) concentrations of As and Mn in all forms similarly increased but the fraction in dissolved form also increased.

Mining operations increases the natural metal fluxes, in both particulate and dissolved forms, in approximately $5,424 \mathrm{~kg}$. week $^{-1}$, or about $60 \%$ of total metal flux, 1,542 kg.week ${ }^{-1}$ or about $49 \%$ of dissolved metal flux and 3,881 kg.week ${ }^{-1}$ or about $66 \%$ of particulate metal flux. Fe flux was responsible for the greatest contribution to the total metal flux from anthropic origin, followed by $\mathrm{Cu}>\mathrm{Zn}>\mathrm{Mn}$. $\mathrm{Cd}$, $\mathrm{As}$ and $\mathrm{Pb}$ showed negligible anthropogenic fluxes.

Potential human health hazards and risk assessment by heavy metals daily intake of water from CCM showed a hazard index (HI) smaller than the unity for the background area, indicating the absence of any probable public health threat. However, for the contaminated area (Station 2), the HI estimated is higher than the unity, and thus, potencial human health effects must be of concern. $\mathrm{Mn}$ is the principal metal responsible for this effect. The ingestion of water from station 2 represents incremental risks of $130 \%$ and $59 \%$, considering the noncarcinogenic and the carcinogenic effects, respectively. For the maximum protection of the human health from the potencial carcinogenic effects due to exposure of chemicals, especially $\mathrm{Cd}$ and As, in drinking water, the ambient water concentration should be zero, based on the non-threshold assumption for these chemicals. The potential human health hazards and risk assessment real increase may be greater than those related to the total concentrations, because the dissolved concentrations of $\mathrm{Mn}$ and As increased more, by factors of 5.5 and 2, respectively.

\section{RESUMO}

As Minas do Camaquã foram a principal jazida de cobre sulfetado do sul do Brasil. Sua explotação foi realizada desde o século passado até 1996. Para avaliar a contaminação da água e o incremento do risco ambiental por metais pesados, relacionados à atividade de mineração, foram amostrados dois diferentes pontos do Arroio João Dias (estação 1, nível de base natural da área e, estação 2, área contaminada). A atividade de mineração aumentou os fluxos semanais naturais de metais pesados em aproximadamente $5424 \mathrm{~kg}(\sim 60 \%)$ de fluxo total, $1542 \mathrm{~kg}(\sim 49 \%)$ de fluxo da fração dissolvida e $3881 \mathrm{~kg}$ $(\sim 66 \%)$ de fluxo da fração particulada. O fluxo total de metais de origem antropogênica deve-se principalmente ao $\mathrm{Fe}$, seguido por $\mathrm{Cu}>\mathrm{Zn}>\mathrm{Mn}$, enquanto os fluxos de $\mathrm{Cd}$, As e $\mathrm{Pb}$ foram desprezíveis. A avaliação do risco 
potencial à saúde humana, relacionado à ingestão diária de água do Arroio João Dias, indica que o risco deve-se, principalmente, ao Mn na área contaminada. A ingestão de água da estação 2 representa um incremento de risco da ordem de $130 \%$ e $59 \%$, considerando os efeitos não carcinogênicos e carcinogênicos, respectivamente. $\mathrm{O}$ incremento real de risco à saúde humana pode ser maior do que aquele relacionado às concentrações totais, uma vez que as concentrações de Mn e As dissolvidas foram 5,5 e 2 vezes maiores respectivamente, do que o aceitável.

Palavras-chave: contaminação aquática, risco ambiental, metais pesados, mineração de cobre.

\section{REFERENCES}

APHA - American Public Health Association. 1985. Standard Methods for Examination of Water and Wastewater. 16 ed., Washington, 1268 p.

BAISCH PRM. 1994. Les oligo-elements metalliques du systeme fluvio-lagunaire dos Patos (Bresil) - Flux et Devenir. Ph.D. Thesis. Université de Bordeaux I, Bordeaux, $229 \mathrm{p}$

Drever JI. 1982. The Geochemistry of Natural Waters. Prentice-Hall, $388 \mathrm{p}$.

Federal Register. 1980. Friday, November 28, v. 45, nr. 231.

Förstner U And Wittmann GTW. 1981. Metal Pollution in the Aquatic Environment. 1.ed. Berlin: Springer-Verlag, $486 \mathrm{p}$.

Hall GEM, Bonham-Carter GF, Horowitz AJ, Lum K, Lemieux C, Quemerais B AND Garbarino JR. 1996. The effect of using $0,45 \mu \mathrm{m}$ filter membranes on "dissolved" element concentrations in natural waters. App Geochem 11: 243-249.

Hatje V, Bidone ED and Maddock JL. 1998. Estimation of the natural and anthropogenic components of heavy metal fluxes in fresh water Sinos River, Rio Grande do Sul State, South Brazil. Environ Technol 19: 483-487.

IAEA - International Atomic Energy Agency. 1990. Evaluation of the Reliability of Predictions Made Using Environmental Transfer Models. Safety Series 100, Vienna.
Kocher DC and Hoffman FO. 1991. Regulating environmental carcinogens: where do we draw the line? Environ Sci Technol 25(12): 1987-1989.

LAybauer L. 1995. Análise das transferências de metais pesados em águas e sedimentos fluviais na região das Minas do Camaquã, RS, Master Science Thesis in Geosciences, Universidade Federal do Rio Grande do Sul, Porto Alegre, 164 p.

LAYBAUER L. 1998. Incremento de metais pesados na drenagem receptora de efluentes de mineração - Minas do Camaquã, Sul do Brasil. RBRH 3(3): 29-36.

LAybauer L ANd Bidone ED. 1998a. Mass Balance Estimation of Natural and Anthropogenic Heavy Metal Fluxes in Streams Near Camaquã Copper Mines, Rio Grande do Sul, Brazil. In: Environmental Geochemistry in the Tropics, Wasserman JC, Silva-Filho EV and Villas-Boas R. (Eds), Berlin: Springer-Verlag, p. $127-137$

LAybauer L And Bidone ED. 1998b. Partição de metais pesados em águas superficiais impactadas por mineração - Minas do Camaquã. Geochim Brasil 12(1/2): 55-62.

Travassos MP And Bidone ED. 1995. Avaliação da contaminação por metais pesados na bacia do Rio Caí-RS através de uma análise dinâmica. In: Desenvolvimento Sustentável dos Recursos Hídricos, 3(1): 205-211.

USEPA - United States Environmental ProtecTION AGENCY. 1989. Risk assessment guidance for superfund. human health evaluation manual. Interim final. USEPA (ed.), Washington, 1, Cap. 4-8, part A.

WiLson AR. 1991. Environmental Risk: Identification and Management. Chelsea: Lewis Publishers, 431p.

ZAPPONI G. 1988. Methods for the health component of industrial development projects. In: International Seminar on Environmental Impact Assessment, 9, Aberdeen, 1988. 20 p. 